\title{
Inflation and the Federal Income Tax
}

The impact of inflation on the federal income tax was the subject of considerable discussion during the 1972 campaign. The debate was initiated by Senator McGovern's proposal, based on "tax justice," that capital gains be taxed as ordinary income. ${ }^{1}$ The present preferential treatment was then defended by the Administration partly on the ground that a great percentage of such gains are "illusory," reflecting nothing more than inflation. ${ }^{2} \mathrm{~A}$ key McGovern adviser responded by noting that interest, dividends, and earned income are taxed in full though they too are affected by inflation. ${ }^{3}$

At present, tax liability depends on income figures computed in terms of nominal dollars with no regard for inflation. ${ }^{4}$ It is true, of

1. The proposal was that "[m]oney made by money should be taxed at the same rate as money made by men, and tax justice demands equal treatment for Americans who earn their living with a shovel or a slide rule and Americans who live on stock market or property gains." N.Y. Times, Aug. 30, 1972, at 22, col. 2. See also Mooncy, Trapped: McGovern and the Analysts, N.Y. Times, Sept. 3, 1972, \$ 3, at 14, col. 2, sug. gesting that the audience of security analysts found the capital gains proposal the worst of all the proposals in the lengthy speech.

In fact, from 1913 until 1921 all income, including capital gains, was taxed at the same rate. For a historical background of capital gains taxation, see U.S. DEP'T of THE Treasury, Federal Income Tax Treatment of Capital Gains and Losses (1951).

2. Treasury Secretary Shultz stated that forty percent of capital gains on common stock realized over the last fifteen years reflected inflation rather than increases in the real value of property. N.Y. Times, Sept. 1, 1972, at 1, col. 4, and 6, col. 4. See also Address by Peter G. Peterson, U.S. Secretary of Commerce, before the Securities Industry Associa. tion, Sept. 6, 1972.

The fact that inflation produces illusory capital gains was recognized as far back as the 1921 congressional committee hearings held to consider taxing capital gains at preferential rates. Hearings on the Revenue Act of 1921 before the Senate Finance Committee, 67th Cong., 1st Sess. 545 (1921). Hearings on Revenue Revision before the House Committee on Ways and Means, 67th Cong., lst Scss. 128-29 (1921).

More recent statements to the same effect are found in L. SEltzer, The Nature and TAX Treatment of Capital Gains and Losses 98-103 (1951); H. Simons, Personal Income Taxation 155 (1938); U.S. Dep'T of THE Treasury, supra note 1, at 19; Cloe, Capital Gains and the Changing Price Level, 5 NAT'L TAX J. 207 (1952); Committce on Salcs, Exchanges and Basis, ABA Section of Taxation, Price-Level Basis Adjustment-A Modest Proposal, 26 TAX LaWyer 189, passim (1973) [hereinafter cited as Committec on Sales]; Smith \& Sullivan, The Taxation of "Real Profit": Towards a Laissez-Faire Revenue Code, 51 NeB. L. REv. 258, 273 (1971); Wallich, Taxation of Capital Gains in the Light of Some Recent Economic Developments, 18 NAT'L TAx J. 138, 137 (1965); Williams, Are Capital Gains and Losses Largely Fictitious?, 12 TAXEs 233 (1934). However, only Wallich defends preferential capital gains rates on this ground.

See also Capital Gains Taxes and Inflation, 1973 TAXATION WITH REPREsentation 67.

3. Letter from Robert $\mathrm{K}$. Lifton to the Financial Editor of the N.Y. Times, N.Y. Times, Dec. 24, 1972, $\$ 3$, at 6 , col. 7 .

4. For example, if fifteen percent inflation were to occur between 1972 and 1975 , then 100 nominal 1972 dollars would be equivalent to $100 \times 1.15$, or 115 nominal 1975 dollars, and 100 nominal 1975 dollars would be equivalent to $100 / 1.15$, or about eighty. seven nominal 1972 dollars. 
course, that inflation affects every type of income. However, it does not affect each type in the same way. The first part of this Note sets forth the major Code revisions that would be necessary to produce a comprehensive system of "real income taxation" from which the effects of inflation would have been eliminated." The second part evaluates such an inflation-neutral system in terms of some of the broader objectives of income taxation.

\section{Adjusting the Tax Code for Inflation}

There are two conceptually distinct ways in which the present Code's reliance on nominal dollar figures fails to account for the effects of inflation. First, in computing gain or loss on a single transaction extending over more than one year, the Code ignores the fact that dollars received or paid in the later year are worth less than those received or paid earlier.

The second effect of the Code's reliance on nominal income is its imposition of an increasing real tax liability on a taxpayer whose nominal income increases from year to year but whose purchasing power remains constant or even decreases due to inflation. This second effect is distinct from the first and occurs whether the income is from wages or transactional gains. It arises from the fixed dollar figures contained in the Code, notably those in deduction allowances and in the tables of tax liability.

\section{A. Income from Transactions Extending Over Time}

\section{Gain or Loss on the Sale or Disposition of Properly}

As a result of inflation occurring between the purchase and sale of an asset, more nominal dollars than were originally spent are necessary to recover the initial cash investment. To the extent that the nominal gain merely recovers the original investment, it is "illusory"

5. The precise impact of inflation on any particular taxpayer depends upon the expenditure patterns of that taxpayer and upon whether those expenditure patierns change during general monetary inflation. Probably the best practical approximation to the general price level movement during inflation, taking into account all items that enter into Gross National Product (GNP), is the GNP implicit price deflator. Accounting Principles Board, Statement No. 3: Financial Statements Restated for General PriceLevel Changes para. 9 (1969). This index is computed quarterly by the Department of Commerce and published in the SuRvey of Current Business. But see Brown. Tax Allowances for Depreciation Based on Changes in the Price Level, I Nat'l TAx J. 311, 313-14 (1948), suggesting that more specific index numbers be used to measure increased costs faced by particular taxpayers. 
rather than "real" income. ${ }^{6}$ This is true for any property with a tax basis, whether or not the item is one which the present Code defines as a "capital asset." 7 The amount needed at any moment to recover the original cost of the asset (in dollars valued as of that moment) is the original cost inflated to that time.

It would be impractical, however, to adjust for the precise amount of inflation which might have occurred between the purchase and sale of an asset. ${ }^{8}$ One possible approximation ${ }^{0}$ would be to account for all inflation which occurred during the year of purchase, and to ignore all inflation during the year of sale, regardless of the particular dates of the two transactions. This system would, however, be subject

6. It has even been suggested that taxation of such gain is unconstitutional, on the grounds that such gain is not "income" under the rationale of Eisner v, Macomber, 252 U.S. 189 (1920). Williams, supra note 2, at 234.

7. INT. REv. CODE of $1954, \S 1221$ "hereinafter cited to section number only].

Inventory goods are a prime example of a class of non-capital assets which would bo subject to the basis adjustment described below. Under the proposals, there would be a sharp narrowing of the present distinction between LIFO (last in, first out) and FIFO (first in, first out) inventory methods of computing the annual deduction for cost of goods sold.

The LIFO method, presently permitted by $\S 472(\mathrm{~b})$, assumes that the goods sold during the year were those most recently purchased. The most recent, and becatise of inflation probably the largest, costs are therefore deducted. The proposed inflation ad. justment would therefore have very little effect on this method.

The FIFO method assumes that the goods sold during the year were those in in. ventory purchased longest ago. The proposed basis adjustment would have a considerable effect on this method, since the deductible cost would consist of the historic cost inflated to the year in question. If the taxpayer's cost of the item of inventory had increased, since the time the earliest inventory on hand was acquired, by cxactly the rate of inflation used in the basis adjustment, the result would be identical to the LIFO outcome.

The use of price indices is not unprecedented in the computation of cost of goods sold. Under the "retail method" department stores approximate the cost of foods on hand by means of a subtraction from the known total retail prices of the goods. Treas. Reg. $\$ 1.471-8(a)(1)(1960)$. If the estimated cost of goods on hand is based on LIFO, the gain or loss in inventory from the preceding year is adjusted for inflation during the year by use of a price index. Treas. Reg. \$ 1.472-1(k) (1961). See also Rev. Rul. 498, 1972 INT. Rev. Bull. No. 42, at 9.

8. Because of the large number of items that must be sampled, actual calculation of day-to-day inflation would not be feasible. In any event, the daily figure would be meaningless because its inherent inaccuracy would certainly dwarf the magnitude of the daily changes in the figure.

Both problems could be avoided by the allowance of a pro rata adjustment to the annual inflation figure, based on the exact number of days during the particular year that an asset was held. Alternatively, a quarterly or semiannual adjustment could be allowed. In fact, depreciation during the year of purchase of an asset is now based on the "half year convention." Treas. Reg. \$ $1.167(a)-11(c)(2)(1971)$ and Temp. Treas. Reg. $\S 12.4$ (d) (1972).

9. The adjustment overcompensates for inflation in the year of purchase, since an asset purchased any time during the year benefits from the full year's inflation ad. justment which would be deserved only for assets purchased on January 1. Converscly, the adjustment undercompensates for inflation during the year of sale, since an asset is treated as if sold on January 1 of that year before any inflation has occurred, even if it is sold on December 31. The net inaccuracy, therefore, depends on the difference between the actual holding period and the next highest or next lowest full number of years. 
to abuse $\mathrm{e}^{10}$ and therefore inflation during a particular calendar year should be accounted for only if the property was held by the taxpayer throughout the year. ${ }^{11}$

Thus, if stock purchased for $\$ 1000$ is sold for $\$ 1200$ after fifteen percent inflation has occurred, $\$ 1150$ of the sale price represents approximately the same value as did $\$ 1000$ in the year of purchase and so merely restores the taxpayer's original cost. Only the remaining $\$ 50$ would be taxable. More generally, taxable gain on any such transaction could be computed by use of a "floating basis" which would increase on the last day of each taxable year by the rate of inflation during the preceding year, as long as the taxpayer had held the asset during the entire year. This basis would thus at any given time reflect the approximate recovery cost of the original asset. An asset purchased for $\$ \mathrm{~A}$ would therefore have a basis of $\$ \mathrm{~A}(1+\mathrm{i})$ after a total of $i$ percent inflation, and a sale for $\$ B$ at that time would result in a taxable gain of $\$ \mathrm{~B}-\mathrm{A}(\mathrm{l}+\mathrm{i}) .{ }^{12}$ This gain will be called the net property gain.

This new adjusted basis ${ }^{13}$ would be used for many purposes other than the calculation of gain. ${ }^{14}$ For example, even if the nominal sale price of an asset exceeds its nominal cost, a real loss has occurred if the former is less than the inflated basis, since the increase in price has not been sufficient to compensate for inflation. Similarly, it is the inflated basis that must be increased by the cost of improvements made to property, ${ }^{15}$ and that must be carried over where appropriate

10. An asset purchased on December 31 and sold for the same price the next day would give the taxpayer a loss measured by the inflation during the entire preceding year.

11. This differs from the previous proposal only by ignoring inflation in the purchase year. An asset would have to be held, depending on the date of purchase, at least one year but not more than two years before any inflation adjustment would be made. This proposal is more favorable to the taxpayer than that suggested in Committee on Sales, supra note 2, at 211-12, where the adjustment would be allowed only for assets held longer than at least two years.

12. This proposal is by no means new. See Cloe, supra note 2, at 209-11; Committee on Sales, supra note 2, at 192-95; Smith \& Sullivan, supra note 2, at 273; Williams, supro note 2, at 233.

13. "Adjusted basis" is used here to mean the basis adjusted for inflation as well as for any other factors. See $\$ 1016$.

14. But see Committee on Sales, supra note 2, at 203, where the adjustment is alled "more clearly deserving" for purposes of gain than of loss.

A different issue is presented by the present overall limitation on total annual capital loss deductions, since the overall limit is based on policy considerations independent of the effects of inflation. See note 105 infra. Nevertheless, a consequence of the floating basis adjustment will be more frequent and greater losses, since the adjustment in every case decreases gain and increases loss (assuming inflation).

15. $\S 1016(a)(1)$. 
from one asset to another of the same taxpayer ${ }^{10}$ or from one to another taxpayer receiving the same asset. ${ }^{17}$

It should be clear by now that inflation does have a greater effect on property gains (which include capital gains) than it does on wage income. The net property gain figure is in nominal dollars of the year the asset is sold, ${ }^{18}$ with the same value as an equal amount of wage income received during the same year. While the floating basis eliminates the extra effect that inflation has on property gains as compared with wage income, a further adjustment, to be described later, ${ }^{10}$ must be made to eliminate completely the effect of inflation from both.

\section{Depreciation Allowances}

Inflation also affects the computation of depreciation allowances, as deductions taken in years following the purchase of an asset are taken in dollars of less value than the dollars spent for the asset. A system of real income taxation requires that the annual depreciation allowances, each valued in purchase year dollars, sum to the nominal purchase price. Stated differently, the annual allowances, if set aside at an interest rate equal to the rate of inflation, ${ }^{20}$ must create a fund which at the end of the asset's useful life is equal to its ${ }^{21}$ inflated cost.

To be sure, present methods of depreciation partially adjust for

16. See, e.g., $\S 358(a)(1)$ (the basis of stock or securities surrendered in certain rcorganizations carries over as the basis of stock or securities received); $\S \$ 1031-39$ (likc kind exchanges in which the basis of property surrendered carries over as the basis of similar property received).

17. See, e.g., $\$ 1015$ (a) (donee's basis of gift property is the donor's basis); $\$ 351$ (transferee corporation takes the transferor's basis); $\$ 332$ (parent corporation takes its subsidiary's basis for property transferred to the parent upon liquidation).

18. Computation of the gain on any purchase and later sale of property, in dollars valued as of any given year requires restating both purchase and sale price in dollars valued as of that year. If an asset is purchased for $\$ A$ and after $i$ percent inflation sold for $\$ B$, the gain in nominal dollars of the year of sale is the sale price $\$ B$ (already in nominal dollars of the proper year) less the purchase price inflated to the year of sale, or $\$ A(1+i)$. The nominal gain, $\$ B-A(1+i)$, is precisely the net property gain computed by the floating basis method. This fact was recognized by Cloe, supra note 2, at 209; Committee on Sales, supra note 2, at 194; Smith \&: Sullivan, supra note 2, at 266; Williams, supra note 2, at 233-34.

19. See pp. 728-35 infra.

20. Interest equal to the rate of inflation is assumed in order that all figures remain constant in real terms regardless of actual inflation. If actual interest rates are higher than this figure, the allowances will in fact accumulate to a fund larger than the in. flated cost. Actual interest rates are irrelevant for present purposes since only the effect of inflation on nominal dollars is being considered, but they do have implications for taxpayer equity. See p. 740 infra.

21. In the first formulation the cost and depreciation allowances arc all valucd in purchase year dollars, while in the second formulation all of the same figures are valued in dollars of a given later year. Equality between the cost and depreciation al. lowances in one year is the same as equality in another year because only the unit of measurement (the value of a dollar in the given year) has changed. 
the effect of inflation, since the depreciation allowances when set aside at interest equal to the rate of inflation would always create a fund greater than the original cost of the asset. Straight line depreciation $^{22}$ accounts. for almost half ${ }^{23}$ of the total intervening inflation; accelerated depreciation ${ }^{24}$ accounts for more than half. ${ }^{25}$ However, the full effect of inflation is presently eliminated only when the entire cost of the asset is deducted immediately upon its purchase, ${ }^{20}$ since in only that case are all deductions taken in terms of purchase year dollars.

It can now be shown that any method of depreciation computed from an asset basis which is adjusted annually to reflect inflation will exactly account for inflation between the asset's purchase and disposal. Assume the initial basis is inflated at the end of the first year, and then reduced by any first year depreciation allowance, and that the reduced basis is then inflated at the end of the second year, and so on until the last year when the entire remaining inflated basis is

22. Straight line depreciation consists of equal annual deductions, spread over the estimated useful life of an asset, summing to the cost (less salvage value) of the asset. $\S 167(\mathrm{~b})(1) ;$ Treas. Reg. $\$ 1.167(\mathrm{~b})-1$ (a) $(1960)$.

23. Assume an asset is purchased for $\$ A$ with a k-year uscful life and that during each year there is $i$ percent inflation. The annual straight-line depreciation allowances of $A / k$ accumulate at the end of the $k$ th year to

$$
(A / k)\left[(1+i)^{k-1}+(1+i)^{k-2}+\cdots+(1+i)+1\right] \text {. }
$$

This is a geometric series with a sum equal to $(A / k) \frac{(1+i)^{k}-1}{i}$. But for the small magnitudes of $i$ in question, $(1+i)^{x}$ is approximately equal to the sum of the first three terms of its binomial expansion, namely $1+k i+\frac{k(k-1)}{2} i^{2}$. With this substitution, the sum of the geometric series simplifies immediately to $A\left[1+\frac{i(k-1)}{2}\right]$.

An accumulation to $A(1+i)^{k}$ would completely adjust for intlation between the purchase and sale. But again using the binomial expansion, this figure is only slightly greater than $A(1+i k)$. Straight line depreciation thus adjusts for approximately $\frac{i(k-1)}{2} / i k$, or $(k-1) / 2 k$, of total intervening inflation. Note that the approximations in the numerator and denominator both result in slightly lower than actual figures and thus partially cancel each other out. Therefore, for assets with a useful life of five years, straight line depreciation makes up for about forty percent of inflation over that time. The figure approaches fifty percent for Ionger useful lives.

24. The various methods of accelerated depreciation involve deductions greater than straight line in the early years and smaller than straight line in the later years, the sum of the deductions always equaling the nominal cost. See $\$ 167(b) ;$ Treas. Reg. $\$ 1.167(\mathrm{~b})-0$ (1960).

25. Since accelerated deductions are taken sooner than straight line deductions, they accumulate to a greater sum at the end of the useful life of the asset.

26. Section 174, for example, permits the immediate write-off of research and development expenditures, even though theoretically such expenditures should be amortized over the useful life of the patent or invention. 
deducted. The depreciation allowances so calculated always accumulate to the inflated cost of the asset. ${ }^{27}$

The apparent complexity of this method might appear to be sufficient reason to reject it. It should be noted, however, that the allowance of depreciation from an inflated basis is inextricably tied to the allowance of loss deductions generated by the floating basis adjustment. If only the latter were allowed, a taxpayer could obtain most of the benefits of the former through a contrived sale..$^{28}$

Furthermore, in the following particular case the method described above results in a greatly simplified method of computation. Using the annually inflating basis, one need only define "straight line" depreciation as follows: The depreciation allowance in any year is determined by dividing the inflated basis at the end of the year by the number of years of useful life remaining, plus one for the yenr in question. ${ }^{29}$ Each annual depreciation allowance under this method

27. The proof is by induction. Such a proof requires showing that a particular hypothesis is true for the first year, and that whenever the hypothesis is truc for any particular year it is also true for the next year. It then follows that the hypothesis is true for every year in question.

The hypothesis to be proven is as follows: At the end of any ycar during the useful life of the asset, the sum of (1) the inflated basis before depreciation is taken that year, and (2) all past depreciation allowances accumulated at the rate of inflation to that moment, equals the initial cost of the asset inflated to that moment.

The proof proceeds as follows: (a) The hypothesis is true at the end of the first year, since there has as yet been no depreciation and the inflated basis is the inflated cost. (b) Assume the hypothesis is true at the end of the $k$ th year. Let $D$ be the ac cumulated value at that time of the prior depreciation allowances, let $B$ be the inflated basis before depreciation at the end of the year, and let $C$ be the cost of the asset in. flated to that time. By hypothesis, $B+D=C$. Assume any depreciation allowance $d$ is taken at the end of the $k$ th year, and that there is $i$ percent inflation during the following year.

It now remains to be proven that the induction hypothesis is true at the end of the following year. The inflated basis at that time is $(B-d)(1+i)$. The accumilated value of the depreciation allowances at that time is the accumulated value of the depre. ciation allowances taken before the $k$ th year, or $\mathrm{D}(1+i)$, as well as one year's accuinu. lation of the $k$ th year depreciation, or $\mathrm{d}(1+\mathrm{i})$. The total accumulated value is thus $(\mathrm{D}+\mathrm{d})(1+\mathrm{i})$. At the end of the year, therefore, the inflated basis plus the accumulated depreciation is equal to $(B-d)(1+i)+(D+d)(1+i)$, or $(B+D)(1+i)$. But since $B+D=C$, the sum is $C(1+i)$. This figure is exactly the initial cost inflated by one more year to the end of the $(k+1)$ st year. Thus the induction hypothesis is true for the $(k+1) s t$ year if it is true for the $k$ th year, and the proof is complete.

28. Assume an inflating basis for capital loss purposes, reduced at the end of cach year by straight line depreciation. At the end of the useful life of the assct, the loss basis will be positive but no further depreciation will be allowed. No loss will be recognized if the asset is discarded, but a loss equal to the remaining basis will be recognized if the asset is sold for a nominal sum. Such transactions would be difficult to attack, particularly since the courts are hesitant to require that a sale have a busincss purpose. See, e.g. Sun Properties v. Comm'r, 220 F.2d 171 (5th Cir. 1955).

29. For example, assume an asset purchased for $\$ 1000$ with a ten year useful life during each year of which there is five percent inflation. At the cnd of the first year, the inflated basis is $\$ 1050$, and the depreciation deduction is one tenth (nine remaining years, plus one) of this, or $\$ 105$. The remaining basis is $\$ 1050$ less $\$ 105$, or $\$ 945$, which inflates at the end of the second year to $\$ 945(1.05)$, or $\$ 992.25$. Depreciation at that 
is equal to the present straight line depreciation allowance multiplied by a factor representing inflation between the purchase year and the year in question. ${ }^{30}$ Thus, this relatively simple method of in. flating present straight line depreciation allowances achieves a result that no present method of accelerated depreciation does-that is, fully eliminating the effects of inflation. ${ }^{31}$ Even though the implied annual basis adjustments could be ignored as long as this method of depreciation were used, the current basis of the asset for purposes of gain or loss on sale could be determined without explicitly computing the prior adjustments. ${ }^{32}$ Finally, it should again be noted that though inflated depreciation figures thus reduce the net income of any asset, that reduced figure is still in nominal dollars of the year

time is one ninth of that figure, or $\$ 110.25$. The remaining basis of $\$ 8 \$ 2$ inflates at the end of the third year to $\$ 926.10$ and depreciation is one eighth of that figure or $\$ 115.70$. This process continues for the entire ten years.

30. In the example in note 29 supra, depreciation for the first three years was \$10J. $\$ 110.25$, and $\$ 115.76$. Observe that $\$ 105=\$ 100(1.05)$, $\$ 110.25=\$ 100(1.05)^{2}$, and $\$ 115.70=$ $\$ 100(1.05)^{3}$. In this case the two methods give the same result. More generally, the equivalence is proved as follows:

Assume an asset purchased for $A$ with a useful life of $k$ years, and assume inflation during the $p$ th year to be $i_{\mathrm{p}}$. Let $I_{\mathrm{p}}$ be the cumulative inflation from the time of purchase to the end of the $p$ th year, so that $\left(1+I_{p}\right)=\left(1+i_{1}\right)\left(1+i_{2}\right)\left(1+i_{3}\right) \ldots \ldots\left(1+i_{p}\right)$.

It will be proved by induction, see note 27 supra, that the modified "straight line" method using an inflating basis gives the same annual depreciation allowances as inflating the present straight line figure. The inflated straight line figure is $(A / \mathrm{h})\left(1+I_{p}\right)$ for the pth year.

(a) The assertion is true for the first year. Use of the inflated basis method gives an inflated basis of $A\left(1+i_{1}\right)$ and a depreciation allowance of $1 / k$ times that, or $A\left(1+i_{1}\right) / k$. This is exactly straight line depreciation inflated for one year.

(b) Assume the assertion is true for some year called the mth. Since inflated straight line depreciation would be $A\left(1+I_{m}\right) / k$, the same depreciation figure is assumed to result from use of the inflating basis. But by the "straight line" formula, the allowance during the $m$ th year is equal to $1 /(k-m+1)$ times the inflated basis at the end of the $m$ th year. The inflated basis before the depreciation allowance was taken must therefore have been $A\left(1+I_{m}\right)(k-m+1) / k$. After the depreciation allowance is taken, this basis reduees to $A\left(1+I_{m}\right)(k-m+1) / k-A\left(1+I_{m}\right) / k$, or $A\left(1+I_{m}\right)(k-m) / k$. Inflating this basis for inflation during the $(m+1)$ st year gives $A\left(1+I_{m}\right)(k-m)\left(I+i_{n+2}\right) / k=A\left(1+I_{a+1}\right)(k-m) / k$. The formula requires that the depreciation allowance at the end of the $(m+I)$ st jear be $1 /(k-m)$ of the inflated basis at that time, or $A\left(1+I_{m+1}\right) / k$. But this figure is exactly the figure resulting from inflating the straight line depreciation figure for inflation during the first $m+I$ years. The assertion is thus true for the $(m+I)$ st year whenever it is true for the $m$ th year.

31. In fact, all present methods of accelerated depreciation can be modified to correet precisely for inflation. Just as for straight line depreciation, each annual allowance is simply inflated to reflect total inflation since the purchase jear; the present allowances sum to the nominal cost, and the inflated allowances will sum to the nominal cost after being deflated to the purchase year. Smith \& Sullivan, supra note 2, at 207, appear to recognize this. Only inflated straight line depreciation, however, is simply related to the three step floating basis adjustment, which is necessary for the direct computation of basis for purposes of sale. See note 30 supra, note 32 infra.

32. A corollary of the proof in note 30 supra is that the asset basis during the $(m+1)$ st year is $A\left(1+I_{m}\right)(k-m) / k$, where $A$ is the cost, $k$ is the useful life, and $I_{n}$ is the total inflation between the purchase and the end of the previous jear. A taxpajer knowing the year of purchase and the useful life of his asset could each year look up in a table the single numerical factor by which his original cost must be multiplied in order to determine the asset basis for the year in question. 
in question ${ }^{33}$ and, as such, is subject to further adjustment for inflation. ${ }^{34}$

\section{Gain or Loss on Fixed Principal Indebtedness}

When a person borrows a sum of money in one year and repays later, intervening inflation means that dollars used to repay the loan are worth less than the dollars initially borrowed. ${ }^{36}$ The decline in the value of a fixed principal repayment obligation thus results in gain to the debtor and loss to the creditor. For example, if there is three percent annual inflation during each year of a loan of $\$ 1000$ payable at the end of five years, at that time $\$ 1000(1.03)^{5}$ or about $\$ 1159$ would be required to repay the actual value of the $\$ 1000$ originally borrowed. Since the required principal repayment is only $\$ 1000$, inflation has given the debtor a gain, and the creditor a loss, of about $\$ 159$ in nominal dollars valued as of the repayment date..$^{30}$

Failure to adjust for this decline in value would be inconsistent with the floating basis adjustment for gain on the sale of an asset. This is perhaps most clearly seen by assuming that the borrower in the example used the $\$ 1000$ to buy an asset which increased in value at the rate of inflation. A sale for $\$ 1159$ at the end of the fifth year would result in no taxable gain by virtue of the floating basis adjustment. ${ }^{37}$ Yet, after using $\$ 1000$ of the $\$ 1159$ sale price to repay the debt, the taxpayer remains with an untaxed gain of $\$ 159 . .^{38}$ The gain on the indebtedness transaction itself does not, of course, depend on what the debtor does with the money.

It should be noted that the adjustment for inflation-induced gains

33. The essential reason is that both gross income and depreciation allowances are in nominal dollars, and thus their difference, which is net income, is in nominal dollars of the same year.

34. See pp. 728-35 infra.

35. It is true that fixed interest payments are also made in nominal dollars of an. nually decreasing value. However, interest payments are deductible when paid and in. cludible in income when received, and the effect of inflation on the nominal value of such payments is fully eliminated by the same adjustment that is made to all nominal income figures. See pp. 728-35 infra. Changes in the value of fixed principal repayment obligations are never reached by the present Code, however, since principal is not dc. ductible when paid and includible in income when received.

36. The principle is somewhat analogous to a debtor's reporting income from the cancellation of part of his indebtedness, Treas. Reg. $\$ 1.61-12(\mathrm{a})$ (1957), and the creditor reporting a bad debt deduction, $\S 166$.

37. See p. 719 supra.

38. Committee on Sales, supra note 2, at 203, refuses to allow the adjustment for principal, seeing no good reason other than "dryly logical and unpragmatic consistency" for requiring the adjustment. The main reason appears to be that parties bargain over interest rates at arm's length and can therefore allocate the loss on principal among themselves. This argument goes too far, however, since parties also bargain at arm's length over the purchase price of all kinds of assets and can thereby allocate the future losses among themselves. See note 97 infra. 
and losses is limited to cash borrowing transactions. It does not extend to property which is rented. ${ }^{38}$ Nor does it extend to future payments made or received pursuant to a commitment made at the time goods or services were received, 40 with the exception of certain consumer installment sales which the Code already treats as loans. 21

When the adjustment does apply, recognition of gain or loss might take place upon repayment of the principal. The magnitude of the adjustment would be the amount of principal repaid multiplied by the total inflation since it was borrowed. In the example, the compound inflation over five years was approximately 15.9 percent, so the debtor has income and the creditor has a loss of $\$ 159$ in nominal dollars.

An alternative method would be to adjust annually for the total gain or loss on all outstanding principal indebtedness in existence during the year. The adjustment on any debt would be the average outstanding indebtedness during the year multiplied by the rate of inflation during that year. ${ }^{42}$ In the example, the debtor's income and creditor's loss would be $\$ 30$ per year.

While the two methods differ in the timing of income recognition

39. Requiring a cash borrower to report income arising from the decreased real repayment obligation is to be treated separately from the question of whether or not to allow recognition of loss to the borrower (depending on what is done with the borrowed cash) arising from the decline in real value of the cash while it is in hand. See pp. 727-28 infra. In the case of rented property, on the other hand, there is no reason not to allow recognition of the loss resulting from the decline in real value of property while it is in hand, any time the gain from returning property of decreased value viould be recognized. Since this gain and loss exactly offset each other, both can be ignored in practice.

40. Suppose $D$ commits himself to pay $\$ 2000$ to $C$ five years hence. $D$ might be an employer for whom $C$ has performed services, or a purchaser of goods from a supplier. Unlike the case where $D$ has presently received 2000 nominal dollars from $C$, the present consideration received by $D$ may be presumed to be the value of $D$ 's commitment, which is less than 2000 nominal first year dollars. Therefore the indebtedness adjustment does not apply to the $\$ 2000$ obligation, the only necessary adjustment being that made to all nominal dollars in the year the $\$ 2000$ is actually paid or received. It should be noted, however, that accrual method taxpayers in this position will discount the $\$ 2000$ to reflect estimated inflation over the five year period before deducting it or taking it into income. See p. 734 infra.

41. Treas. Reg. \$ 1.163-2 (1969) permits certain installment purchasers of personal property to deduct as interest a percentage of their average outstanding balance cren though the installment sale is not written in the form of a loan. Since the Code treats such transactions as cash borrowing for purposes of the interest deduction, they an be treated as cash borrowing for purposes of the principal adjustment.

42. Assume that a debtor has an outstanding principal obligation of $\$ B$ throughout a year during which $m$ percent inflation occurs. The principal oblipation in dollars valued as of the beginning of the year is clearly $\$ B$. This initial obligation expressed in dollars valued as of the end of the year is $\$ B(1+\mathrm{m})$. In dollars valued as of the end of the year, therefore, the obligation has been reduced from $\$ B(I+m)$ to $\$ B$, a gain in such dollars of $\$ \mathrm{mB}$. The creditor has an identical loss of $\$ \mathrm{mB}$ on principal owed him. If the amount of indebtedness varies during the jear and inllation is assumed to be constant throughout the year, the formula is reasonably correct when applied to average indebtedness. 
they are equivalent in real terms because postponed adjustments are made in greater amounts. ${ }^{43}$ Both methods have analogies in the present tax realization rules. ${ }^{44}$ The annual adjustment method is suggested, however, because it can be used in tandem with the present interest deduction. The combination of principal and interest adjustments results in debtors deducting interest and creditors taking interest into income only to the extent that it exceeds the rate of inflation. As a result, debtors and creditors would not have to account for the actual amount of principal indebtedness, which may vary throughout the year. Rather they need deduct or report as income simply a fixed percentage of the interest paid or received reflecting the rates of inflation and interest on the loan. ${ }^{45}$ For example, if the interest rate is five percent and the rate of inflation is three percent, exactly $(5-3) / 5$ or forty percent of the interest paid or received is to be deducted from or included in income. Allowing the debtor's income as an offset to the interest deduction results in no additional tax liability for debtors presently taking the standard deduction ${ }^{46}$ and should in fact increase its attractiveness. ${ }^{47}$

43. The underlying principle is exactly the same as that involved in the real cquiva. lence of all methods of depreciation off of an annually inflating basis. See p. 721 supra. An anntual deduction for the decreased value of the principal obligation is analogous to annual depreciation allowances which just eliminate the annual inflation of the basls. An adjustment for principal only upon its repayment is analogous to a single depreciation allowance at the end of the term equal in size to the total basis inflation to that time. Since the two methods of depreciation are equivalent when the asset basis is reduced to zero at the end of the term, they are also equivalent when the basis is only reduced to its initial value at the end of the term.

44. The adjustment upon repayment of principal is analogous to the present treat. ment of foreign currency which is purchased with dollars. The foreign currency is treated as a capital asset, and despite intervening exchange rate fluctuations no gain or loss is recognized until the currency is reconverted into dollars. I.T. 3810, 1946.2 CUM. BUL. 55.

On the other hand, the annual adjustment method is supported by the present treatment of original issue bond discount, in which the creditor takes part of the discount into income each year even though no cash is received until the bond is redcemed, $\$ 1232(a)(3)$, and the debtor takes a pro rata annual interest deduction though no cash is paid until redemption, Treas. Reg. $\$ 1.163-3(\mathrm{a})(1968)$.

The usual rule that income is not realized until an asset is disposed of is not ap. plicable here to the extent that the rule is based on the notion that cash to pay the tax liability will not generally be available until disposition. The debtor, who must report an item of income, will not have any cash available merely by repaying principal. In fact, viewing that income as an offset to the interest deduction, see p. 726 infra, the debtor is probably more able to recognize the gain annually by simply deducting less interest. Likewise, the receipt of a principal repayment is not the traditional occasion for allowing recognition of loss, and a creditor might just as well reduce his reported interest income annually.

45. It is not necessary that the principal indebtedness be constant throughout the year, since the total interest paid or received measures the average indebtedness during the year, and it is on the latter figure that the adjustment for inflation is to be made.

46. A reduction in deductible expenses has no effect on the tax liability of taxpaycrs taking the standard deduction because that deduction substitutes for individual deductions. All creditors, on the other hand, would have their tax liability decreased under this method, since interest income goes directly into adjusted gross income and a reduction in the former is a reduction in the latter.

47. By decreasing the overall size of deductions, the adjustment results in fewer taxpayers having total deductions greater than the standard deduction. 
The same adjustment must be made for deposits in interest bearing bank accounts, which, of course, also decrease in value because of inflation. ${ }^{\$ 8}$ Depositors would take into income, and banks would deduct, only a portion of the entire interest received or paid. ${ }^{* 0}$

A further consideration is the treatment of debtors and creditors when the rate of interest on a loan or bank account is less than the rate of inflation. In theory, the debtor's gain from the reduction in repayment obligation would be greater than his interest expense, and the creditor's loss would be greater than his interest income. The debtor would have net reportable income, while the creditor would have a net deduction. ${ }^{50}$ Failure to take these net items into account would be equivalent to recognizing income from declining real principal obligations to the arbitrary extent that interest is paid on the principal, and allowing recognition of loss on principal only to the extent that income is received on the principal.

Rigorous application of the basic principle would require that an identical adjustment be made for currency held by a taxpayer throughout a year, since its value at the end of the year is reduced because of inflation. ${ }^{j 1}$ However, administrative difficulties would likely be insurmountable in all but those cases where individuals or institutions maintain a clearly ascertainable cash balance.52 An exception to the allowance of net losses to creditors might also be made for sums

48. The considerations in favor of annual adjustments for decline in principal value are particularly strong in the case of bank deposits. Just as interest credited to an account is taxed whether or not withdrawn, Treas. Reg. $\$ 1.451-2(b)$ (19G1), so should losses on the principal be taxed annually whether or not the principal is withdrawn. Furthermore, the alternative treatment would allow taxpayers to accumulate large potential losses which they could recognize at will by the withdrawal of principal from the account. See note 105 infra.

49. The percentage adjustment is precise only if interest is paid on a day-of-deposit to day-of-withdrawal basis. If not, the actual interest credited understates the assumed average principal balance during the year, reducing the inflation deduction to which the depositor was entitled and the inflation gain which the bank would have had to include in income. The inaccuracy would, however, be minor.

50. For example, a student receiving a low-interest cducation loan might have net income to report, while the bank making the loan (if not subsidized by the government) would have a net loss. A bank depositor with money in an interest-free Christmas Club account would have a net loss, while the bank in that case would have net income of the same amount.

51. The required adjustment applies only to currency rather than to all assets held by a taxpayer. Inflation affects the unit in which asset values are mosured, but does not affect the real value itself. Changes in real asset values are measured by the noating basis adjustment. See pp. 717-20 supra.

52. In a year of three percent inflation, the taxpayer who kept $\$ 5000$ in his mattress throughout the year would claim a loss of $\$ 150$. and the taxpayer who kept an acerage of $\$ 100$ cash in hand during the year would claim a loss of $\$ 3$.

The difficulties would be less, for example, for a bank which conld prove holding an average cash inventory of, say, $\$ 1,000,000$. The $\$ 30,000$ loss should be allowed; this loss in real value of cash is a cost of doing business.

The two extremes might be reconciled by first allowing a loss on currency only above a minimum sum (which should inflate annually, see p. 731 infra), and then only if an administratively feasible method of proof could be devised. 
maintained in checking accounts. In such cases the loss is somewhat offset by nontaxable services received by the depositor ${ }^{53}$ and, even in theory, a loss on principal should be allowed only to the extent that principal exceeds checks outstanding against the account. ${ }^{54}$

\section{B. Adjusting Nominal Income for Inflation}

The inflation adjustments proposed thus far have corrected for the effect of inflation in computing gain or loss on single transactions. In each case, the resulting figure for gain or loss was in nominal dollars of the year it was to be included in income, ${ }^{55}$ and thus equivalent to the same amount of wages earned during the same year.

Once all income figures are in nominal dollars, however, full elimination of the effects of inflation requires an additional adjustment. Tax burden should not be affected by the fact that increasing amounts of nominal income are needed each year, because of inflation, for total purchasing power to remain constant. Assuming that both nominal income and deductible expenses increase at the rate of inflation, ${ }^{, 0}$ tax liability should also increase at that rate. A constant real income should incur a constant real tax.

"Income" here includes all gain from any source whatever, except that the adjustments described in the last section ${ }^{57}$ are made first. If nominal tax liability were directly proportional to this modified income figure, both would increase at the same rate and no further adjustment would be necessary.

53. Presumably a bank would increase the charge for checking account services if it paid interest on checking account balances. The imputed service income reccived by depositors is not now taxed, even though interest received in lieu of it would be taxcd. R. GoOde, THE Individual Income Tax 148 (1964), estimates a total interest loss on such accounts at \$11.1 billion. Denying depositors a loss on principal of such accounts is equivalent to imputing income equal to interest at the rate of inflation.

In any event, the bank would still have to report gain on the decreasing value of its repayment obligation. This is necessary to offset the bank's deduction as a busincss expense of the cost of providing services to the depositor. The tax consequences to the bank should not turn on whether it pays interest or provides services of cqual valuc.

54. The drawer on a check is in a sense a debtor until the chcck clears his account, and as such would have a gain on that amount of principal for the interim period. Such a gain would exactly offet the loss on the same amount of principal in the checking account.

55. See pp. 720, 723-24 supra.

56. The present Code computes tax liability by relying on the size of decluctible expenses as well as on total nominal dollars of income. If, in real terms, nominal income remains constant but fully deductible expenses decline, then it is consistent with the inflation adjustment that real tax liability should increase. The discussion in the text assumes that these deductible expenses increase at the rate of inflation.

The assumption does not extend to expenses for which only a limited deduction is granted. See note 75 infra. In those cases the deduction is not intended to mcasure the expenses of an individual taxpayer, but rather to treat all taxpayers as if their expenses were average. It need only be assumed in such cases that taxpayers on the whole increase these expenses at the rate of inflation.

57. See pp. 717-28 supra. 
The present computation of nominal tax liability is, however, con. siderably more complex. First, all items of income with certain specified exceptions are combined to form gross income. ${ }^{58}$ Certain items are then deducted to derive adjusted gross income (AGI); ${ }^{53}$ other items are then deducted to reach taxable income. ${ }^{60}$ Finally, the tax rate tables determine the nominal tax liability due on any nominal taxable income. ${ }^{61}$

At present, a constant real income will incur an increasing real tax. Consider a married couple with two children, a total 1972 income of $\$ 8000$, and no optional exclusions or deductions. If they take the standard deduction with the low income allowance, their taxable income is $\$ 3700$ and tax liability is $\$ 569$. If the couple's income just keeps pace with succeeding inflation of fifteen percent, AGI increases fifteen percent to $\$ 9200$, but taxable income increases thirty percent to $\$ 4820$, and tax liability increases thirty-six percent to $\$ 776 .^{\circ 2}$ Of the $\$ 207$ increase in tax liability, $\$ 85$ represents the fact that taxes are being paid in cheaper dollars while \$122 represents an increase in real tax burden.

The illustration shows that the disparity between real income and real tax burden arises from two factors. First is the system of income exclusions and deductions; second are the tax rate tables themselves. A different adjustment must be made to eliminate the contribution of each to the overall disparity. The first adjustment will ensure that constant real income and expenses result in a constant real taxable income. The second will ensure that a constant real taxable income will then result in a constant real tax liability.

\section{The Calculation of Taxable Income}

Taxable income is derived by the exclusion of certain income and the deduction of certain expenses from gross income. ${ }^{03}$ It should be obvious that if total income increases at the rate of inflation, but the allowable exclusions and deductions increase at less than that rate, the difference between the two, taxable income, will increase by more than the rate of inflation.

58. The all-inclusive definition of gross income contained in $\S 61$ is modified by $\$ \S$ $101-23$.

59. $\$ 62$.

61. \$1.

62. The standard deduction in the first year is the minimum standard deduction of $\$ 1300, \S 141(a)$, (c), while in the second case it is the percentage standard deduction of fifteen percent of $\$ 9200$, or $\$ 1380, \$ 141(b)$. In each case there are four personal exemptions of $\$ 750$ each. $\$ 151$.

63. See discussion this page supra. 
In certain instances an allowable exclusion from gross income in. creases at the same rate as total income of the same kind. Similarly, certain deductions from gross income will increase at the rate of inflation when the out-of-pocket expense does. This will be true when an item is fully excludible ${ }^{04}$ or fully deductible ${ }^{05}$ from gross income. Moreover, it is true as to exclusions and deductions which consist of: (1) a fixed proportion of certain expenses, ${ }^{60}$ (2) all or a fixed proportion of certain expenses, up to a fixed proportion of income, ${ }^{07}$ (3) all of certain expenses to the extent they exceed a fixed proportion of income, ${ }^{68}$ or (4) the standard deduction, in those income ranges where it is a fixed proportion of AGI.00

However, there are two significant deductions which are allowable only as a fixed sum: the personal exemption and, for certain income ranges, the standard deduction. ${ }^{70}$ In addition, other items are excluded $^{71}$ or deducted $^{72}$ from gross income only to the extent that they do not exceed a fixed maximum. Because of inflation, the real value of these fixed deductions and maxima decrease from year to year. Only slightly offsetting are other deductions allowed for expenses in excess of a fixed sum, ${ }^{73}$ the non-deductible portion decreasing in real value from year to year. On the whole, therefore, exclusions and deductions do not increase at the rate of inflation from year to year even if the underlying income and expenses do. ${ }^{74}$

This analysis suggests a simple annual adjustment to the Code which will increase overall deductions and produce a constant real taxable

64. E.g., $\$ 103($ a) (interest on certain government bonds).

65. E.g., \$163(a) (interest); $\$ 164$ (a) (certain taxcs).

66. E.g., $\$ 213(a)(2)$ (allowing the deduction of one half of medical insurance pre. miums). Cf. note 72 infra.

Falf of presently computed net long term capital gains are deducted from gross in. come. $\$ 1202$. Assuming that net property gains is used instead, any fixed fraction of such gains could be deducted without affecting the inflation adjustment. Dut set p. 790 infra.

67. E.g., $\$ 170(\mathrm{~d})(\mathrm{I})(\mathrm{A})$ (limiting the charitable deduction in some cases to fifty percent of $A G I$ ).

68. E.g., $\$ 213(a)(1)$ (allowing the deduction of medical expenses only to the cxtent they exceed three percent of $A G I)$.

69. The standard deduction is fifteen percent of AGI, with a minimum of $\$ 1300$ and a maximum of $\$ 2000$. $\$ 141$. Thus only in the AGI range $\$ 8700-\$ 13,400$ (approximatcly) are taxpayers subject to a strictly proportional deduction.

70. The personal exemption is $\$ 750$. \$151. See also note 69 supra.

71. E.g., $\$ 116$ (excluding the first $\$ 100$ of dividend income received); $\$ 101(b)(2)(A)$ (excluding tu to $\$ 5000$ of employee death benefits); $\$ 121(b)(1)$ (excluding gain on certain property to the extent that the sale price is under $\$ 20,000)$.

72. E.g., $\$ 163(\mathrm{~d})(1)(\mathrm{A})$ (restricting the deduction of interest in excess of $\$ 25,000$ on investment indebtedness); $\$ 213(\mathrm{a})(2)$ (limiting medical insturance premium deductions to $\$ 150) ; \$ 218(\mathrm{~b})(1)$ (limiting political contribution deductions to $\$ 50$ on a joint re. turn); $\$ 1211(\mathrm{~b})(\mathrm{I})(\mathrm{B})$ (limiting capital loss deductions to $\$ 1000$ annually).

73. E.g., \$ $165(\mathrm{c})(3)$ (allowing the deduction of casualty losses in excess of $\$ 100$ ).

74. It is clear that the losses to taxpayers from not bcing able to inflate their cx. emptions and standard deductions far overshadow their gains from being able to deduct a few real dollars more on casualty losses. 
income for a constant real total income, assuming constant real de. ductible expenses. ${ }^{\top 5}$ Any fixed dollar amount (whether as a maximum, minimum, or flat amount) used in computing any exclusion or deduction should be increased annually by the rate of inflation during the preceding year.

The adjustments affect taxpayers taking the standard deduction as well as those who itemize. The standard deduction is but a substitute for certain itemizable deductions and will itself increase at the rate of inflation; and in any event all taxpayers are entitled to other deductions and the same exclusions from gross income. ${ }^{i s}$ In the example above, ${ }^{77}$ these adjustments would produce a taxable income of $\$ 4255$ in the later year, ${ }^{78}$ which is the desired fifteen percent above the taxable income of the earlier year.

The adjustments would be administratively simple and could be calculated in advance and printed on tax return instructions. In each case, the taxpayer would simply add or subtract a larger fixed sum in computing his taxable income. ${ }^{79}$

\section{The Calculation of Nominal Tax Liability}

Inflation of fixed deductions reduces but does not completely eliminate the disparity over time between real income and real tax liability. In the example, the taxable income of $\$ 4255$ derived by inflating deductions results in a tax liability of $\$ 668$, an increase of seventeen percent for a fifteen percent increase in both total income and taxable income. The remaining disparity results from the tax rates themselves. Because the rates are progressive, ${ }^{80}$ tax liability increases faster than taxable income when the latter increases only at the rate of inflation. ${ }^{81}$

75. There will be many taxpayers who will gain from one or more of the adjustments even though their expenses in a particular area did not increase at the rate of inflation. For example, the taxpayer for whom support of a dependent cost $\$ 700$ (or $\$ 800)$ in each of two years would still get to deduct $\$ 750$ in one year and a larger amount the next year. This is acceptable as long as average expenses of taxpayers increase at the rate of inflation. See note 56 supra.

76. Taxpayers electing the standard deduction remain subject to the exclusions and deductions from gross income in computing AGI, and the deduction of the personal exemption from AGI to reach taxable income. The deductions precluded by the clection of the standard deduction are other deductions from ACI to reach taxable income. See $\$ 63(a)$.

77. See p. 729 supra.

78. Each personal exemption would increase to $\$ 862.50$, for a total of $\$ 3450$. The taxpayer in the later year would take the inflated minimum standard deduction of $\$ 1495$. Deducting both figures from the AGI of $\$ 9200$ yiclds taxable income of $\$ 4255$.

79. Equally significant, the adjustments can be automatically factored into the printed tables which compute tax liability directly from AGI for most taxpayers who take the standard deduction.

80. If tax liability were proportional to taxable income, the adjustments discussed in this section would be unnecessary. See p. 728 supra.

81. See Altman, The Brackets Make Inflation Deflationary, 24 TAxis 931 (1946). 
Since real tax liability on a given real taxable income presently varies from year to year, some base year must be chosen as a standard. The adjustment to be made will result in real tax liability over time remaining equal to the real tax liability in the base year, given a constant real income.

In theory, a three step computation of nominal tax liability would achieve the desired result: Assume total inflation of $I$ percent between the base year and the year $Y$, and nominal taxable income in year $Y$ of $\$ A$. First, deflate $\$ \mathrm{~A}$ to the base year to obtain a taxable income in base year dollars of $\$ A /(1+I)$. Second, compute the tax due in the base year on the taxable income of $\$ A /(1+1)$. Third, inflate that tax liability by $(1+I)$ to account for the fact that the tax is to be paid in year $\mathrm{Y}$ rather than in the base year. In short, the nominal tax liability on a taxable income of $\$ \mathrm{~A}$ is to be $(1+\mathrm{I})$ times the base year tax liability on $\$ \mathrm{~A} /(1+\mathrm{I}) .^{82}$ Applied to the example above, this three step computation combined with inflated deductions gives a tax liability of $\$ 654$, exactly fifteen percent above the earlier liability and thus equivalent in real terms. ${ }^{83}$

Actual institution of this adjustment would not be nearly as complex as might appear at first glance. A simple annual adjustment to the tax rates would make it possible for the taxpayer to compute taxable income as at present (using inflated deductions), and then use altered tables to compute directly the same tax liability which would result from the three step process.

Tax liability is presently determined by applying the following marginal rates to taxable income:

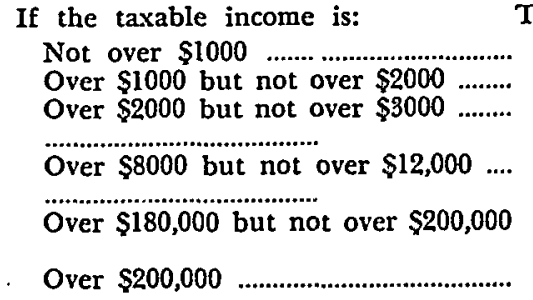

82. As would be expected, the three step process has no effect on nominal tax liability when the tax rates are strictly proportional to taxable incomc. If the rate is $r$ percent of taxable income, the three step process results in $(1+1)$ times the base year $\operatorname{tax}$ on $\$ A /(1+I)$, or $(1+I)$ times $\$ r A(1+1)$, or $\$ r A$, which could have been computed directly.

83. First, deflate the taxable income of $\$ 4255$ derived by inflating deductions by the assumed fifteen percent rate of inflation, getting $\$ 3700$. Second, the 1972 tax liability on $\$ 3700$ is $\$ 569$. Third, inflating $\$ 569$ by fifteen percent gives $\$ 654$, which is the desired fifteen percent greater than the 1972 tax of $\$ 569$.

84. See § 1(a). 
The adjustment proposed is that the widths of the brackets increase annually at the rate of inflation, thus remaining constant in real terms. The bracket widths would therefore reflect total inflation since the base year. After fifteen percent inflation, the table would read:

If the taxable income is:

Not over $\$ 1150$

Over $\$ 1150$ but not over $\$ 2300$

Over $\$ 2300$ but not over $\$ 3450$

Over $\$ 9200$ but not over $\$ 13,800 \ldots$

Over $\$ 207,000$ but not over $\$ 230,000$

Over $\$ 230,000$
The tax is:

14 percent of taxable income.

$\$ 161$, plus 15 percent of the excess over $\$ 1160$. $\$ 334$, plus 16 percent of the excess over \$2300.

$\$ 1587$, plus 22 percent of the excess over $\$ 9200$. $\$ 111,757$, plus 69 percent of the excess over $\$ 207,000$.

\$127,627, plus 70 percent of the excess over $\$ 230,000.85$

Since such adjustment is equivalent to the three step process, ${ }^{80}$ use of the adjusted tables will result in a constant real tax liability on a constant real taxable income.

The adjusted rate structure compensates for the fact that all figures which go into the computation of taxable income are in terms of nominal dollars whose real value is affected by inflation. From one congressional action to the next, tax rates would remain constant in real terms. At any time, of course, Congress could superimpose a

85. Although the effects would be trivial, the same adjustment conld be made to corporate rates. Present corporate rates are twenty-two percent of the first $\$ 25,000$ of taxable income and forty-eight percent of the excess. \$11. The adjustment simply inflates the $\$ 25,000$ figure annually. Five percent annual inflation would decrease each corporation's taxes by an additional $\$ 325$ per year.

86. Call the base year table of rates Table $A$, and call the table inflated to reflect a total of $I$ percent inflation since the base year Table B. Assume a taxable income of $\$ X$ in the later year. To show that use of Table $B$ is equivalent to the three step process, it must be shown that the tax on $\$ X$ computed directly by Table $B$ is equal to the tax on $\$ \mathrm{X} /(1+1)$ computed by Table $A$, multiplied by $(1+1)$.

Assume $\$ X$ is in some bracket in Table $B$, of the form "If the taxable income is over $\$ U$ but not over $\$ V$, the tax is $\$ T$ plus $r$ percent of the excess over $\$ U . "$ (The proof is analogous if $\$ X$ is in the highest or lowest brackets, which are of different forms.) The tax on $\$ X$ as computed by Table $B$ is then equal to $\$ T+r(X-U)$.

Since each bracket level in Table $B$ is derived by inflating bracket levels in Table $A$, there must be a line somewhere in Table $A$ of the form "If the taxable income is over $\$ U(1+I)$ but not over $\$ V !(1+I)$, the tax is $\$ T /(1+I)$ plus $r$ percent of the excess over $\mathrm{SU} /(1+\mathrm{I}) . "$

But it is now a simple matter to find the tax on $\$ \times /(1+I)$ as computed by Table A. Since $\$ X$ is between $\$ U$ and $\$ r$, it must be true that $\$ X /(1+I)$ is between $\$ U /(1+I)$ and $S V /(1+I)$. Applying the formula in the preceding paragraph, the tax on $\$ \times(1+1)$ is $\$ T /(1+I)$ plus $r[\$ X /(1+I)-\$ U /(1+I)]$. Mfultiplying this figure by $(1+I)$ gives $\$ T+r(X-U)$, which is exactly the tax on $\$ X$ computed directly by use of Table $B$. Use of Table $B$ is thus equivalent to applying the three step process and using Table A. It should be noted that the equivalence is based on the fact that when the brackets and taxable income both inflate at the same rate, taxable income remains in the same bracket at all times. 
new set of rates: The year of such a congressional amendment would in effect become a new base year, the new bracket width increasing at the rate of inflation.

\section{G. Timing Factors}

The adjustments made thus far have been based on the assumption that all gains and losses are taxed in the year that income is received. In a few instances, however, this assumption is incorrect, as tax liability may take into account items of income received in another tax year. In such cases the income received must be inflated or deflated to the year in which the tax is to be paid.

The most obvious adjustment applies to accrual method taxpayers. ${ }^{87}$ Whenever income is to be reported before or after it is received, the amount must be inflated or deflated to the year of inclusion. The same principles would apply to deductions taken before or after the actual expenditure was made.

Adjustments would also be necessary for some cash method taxpayers. First, under the loss carryback and carryover provisions, ${ }^{88}$ recognized losses greater than the maximum allowable annual deduction $^{80}$ are treated as if incurred in an earlier year. An inflationneutral Code would require that these losses be deflated to the earlier year. Any refund on prior years' taxes would include interest at the rate of inflation. ${ }^{00}$ Similarly, if the carryback provisions were insufficient and the losses were carried over to offset future profits, the excess loss should be inflated annually. Income averaging provisions ${ }^{01}$ would require a similar adjustment: Taxable income of one yenr, when treated as if earned in another, must obviously be inflated or deflated accordingly.

Finally, a change would have to be made in the judicially created tax benefit rule. Under that doctrine, when a taxpayer takes a deduction to which he was not entitled, the taxpayer must take, at the later time, the same amount into income. ${ }^{22}$ The rule would have to

87. $\S 446(c)(2)$.

88. See, e.g., § 1212 (capital losses); § 172(b) (net operating losses); § 170(d) (carryover of excess charitable contributions).

89. This maximum allowable deduction must at the same time be inflated annually. See p. 731 supra.

90. Such interest is presently not granted. $\S 6611(f)$.

91. $\$ \$ 1301.05$.

92. See B. Bittker \&: L. Stone, Federal Income, Estate, and Gift Taxation 86.90, 883-84 (1972). 
be altered so that the amount taken into income is equal to the original deduction inflated to the year it is to be reported as income.

\section{Inflation Neutrality and Tax Policy}

Although many of the proposed technical adjustments which correct for inflation may be administratively feasible, there are other more important grounds for evaluating such a thorough revision of the Code. This section will suggest some of the effects inflation neutrality would have on horizontal and vertical equity, revenue yields, and macroeconomic stabilization.

Two preliminary observations should, however, first be made. The present system clearly allows Congress to increase taxes by inaction, since the real tax burden increases every year for which Congress does not lower tax rates. Of course, Congress does periodically adjust brackets so as roughly to cancel out the real increases in tax burdens due to inflation; ${ }^{33}$ but these periodic revisions are enacted with great fanfare as "tax cuts," 94 even though they may merely cancel years of hidden tax increases. ${ }^{95}$ An inflation-neutral system should therefore enhance the accountability of government for both tax increases and reductions, since all enactments would then be in real terms. The second point is simply that the effects of the present system are haphazard. If some of the effects of inflation were deemed desirable, they could be achieved more equitably by annual amendments of a real tax system. But few presently concern themselves with the obscurebut very real-effects of inflation.

93. See Statement of Henry C. Wallich, Hearings on the Economic Report of the President Before the Joint Economic Committee, 92d Cong., 2d Sess., pt. 3, at 490 (1972).

94. See, e.g., The 1972 Republican Party Platform, N.Y. Times, Aug. 22, 1972, at 35, col. 4 .

95. For example, the Republican Party Platform, id., asserted that a taxpayer with a 1971 AGI of $\$ 10,000$ to $\$ 15,000$ paid thirteen percent less tax after the 1969 Tax Reform Act and the Revenue Act of 1971 . While no doubt true in nominal terms, the claim over. looks the fact that the real tax burden borne by these taxpayers was identical to or greater than that borne by taxpayers with equivalent real incomes in 1984. The following table assumes a married couple with two dependents who file a joint return and take the standard deduction:
(a) 1971 tax
(b) Equivalent 1964 AGI
(c) 1964 tax on equivalent 1964 AGI
(d) 1964 tax in 1971 dollars
(e) Percent change in real tax burden since 1964

$\begin{array}{cc}\text { Taxpayer with } 1971 \text { AGI of } \\ \$ 10,000 & \$ 15,000 \\ 1,000 & 1,996 \\ 7,650 & 11,475 \\ 777 & 1,465 \\ 1,016 & 1,915 \\ -1.6 & +4.2\end{array}$

Similar conclusions can be drawn from the data presented by Wallich, supra note 93 , at 490 . 


\section{A. Equity}

\section{Horizontal Equity}

The basic argument for relying on real rather than nominal income rests on the concept that individuals with the same real income should be taxed at the same real rate. ${ }^{96}$ Because of its reliance on nominal dollars, the present system fails to meet this condition in two respects. First, an individual with a constant real income may be taxed at different rates at different points in time. Moreover, measurement of income in nominal terms produces inequities between individuals having identical real incomes at the same point in time.07 For example, two taxpayers with the same real income will be taxed differently depending on their relative indebtedness. Similarly, taxpayers who own property may have their real income overstated because present depreciation and the calculation of gain or loss is based on historical cost.

The present preferential treatment of capital gains makes horizontal equity analysis more difficult. Depending on the holding period, the rate of inflation, and the rate at which a capital asset appreciates, the present treatment of capital gains may or may not result in a higher real tax burden than if the smaller net property gain figure representing the real income component were fully taxed as ordinary income. The holding period and the rate of inflation determine a critical rate of price appreciation. ${ }^{98}$ When capital assets appreciate faster (or slower) than the critical rate, the present system levies a lower (or higher) effective tax burden on the real component of capital gains than on the equivalent "ordinary" real income.

Defenders of the present treatment of capital gains ${ }^{90}$ usually point

96. A leading commentator recognizes that in principle the index of equality should be measured in real terms, but dismisses the idea as "hardly possible in practice." $R$. Muscrave, The Theory of Public Finance 168.69 (1959).

97. If inflation could be perfectly anticipated by all taxpayers, there would, in theory, be no redistribution of wealth or tax burdens: Wage earners would demand higher nominal wages which would take account of the increased real tax burden duc to in. flation; creditors would demand higher rates of interest to compensate for pricc level changes; and debtors would be willing to pay such higher nominal rates. $A$ certain amount of redistribution of wealth, however, can be expected in the short run since future rates of inflation cannot be predicted with certainty. See Budd \& Sciders, The Impact of Inflation on the Distribution of Income and Wealth, 61 AM. ECoN. REV. 128 (Papers and Proceedings 1971).

98. It can be shown that the critical rate is $r^{*}=\left[2(1+i)^{t}-1\right]^{\frac{1}{t}}-1$, where $i$ is the com. pound annual rate of inflation and $t$ is the holding period of the asset. Smith \& Sullivan, supra note 2, at 273-75.

99. See N.Y. Times, supra note 2, at 1, col. 4; Address by Peterson, supra note 2. 
to the possibility that property gains may still be overtaxed when compared with wage income.100 On the other hand, tax reformers who would completely abolish the preferential rate structure point to the possibility that it may undertax property gains. ${ }^{101}$ Both groups ignore the fact that the present preferential treatment of capital gains will result in the overtaxation of some and the undertaxation of others. It is therefore difficult to determine who is "more" correct or whether the present capital gains tax structure produces a rough kind of justice. $^{102}$

100. In the formula given in note 98 supra the critical rate $r^{\circ}$ approaches the compound annual rate of inflation $i$ as the holding period increases. Thus so long as the actual rate of return $r$ is greater than the rate of inflation, there will be a holding period $p$ after which the capital asset holder is undertaxed. This point is illustrated graphically below.

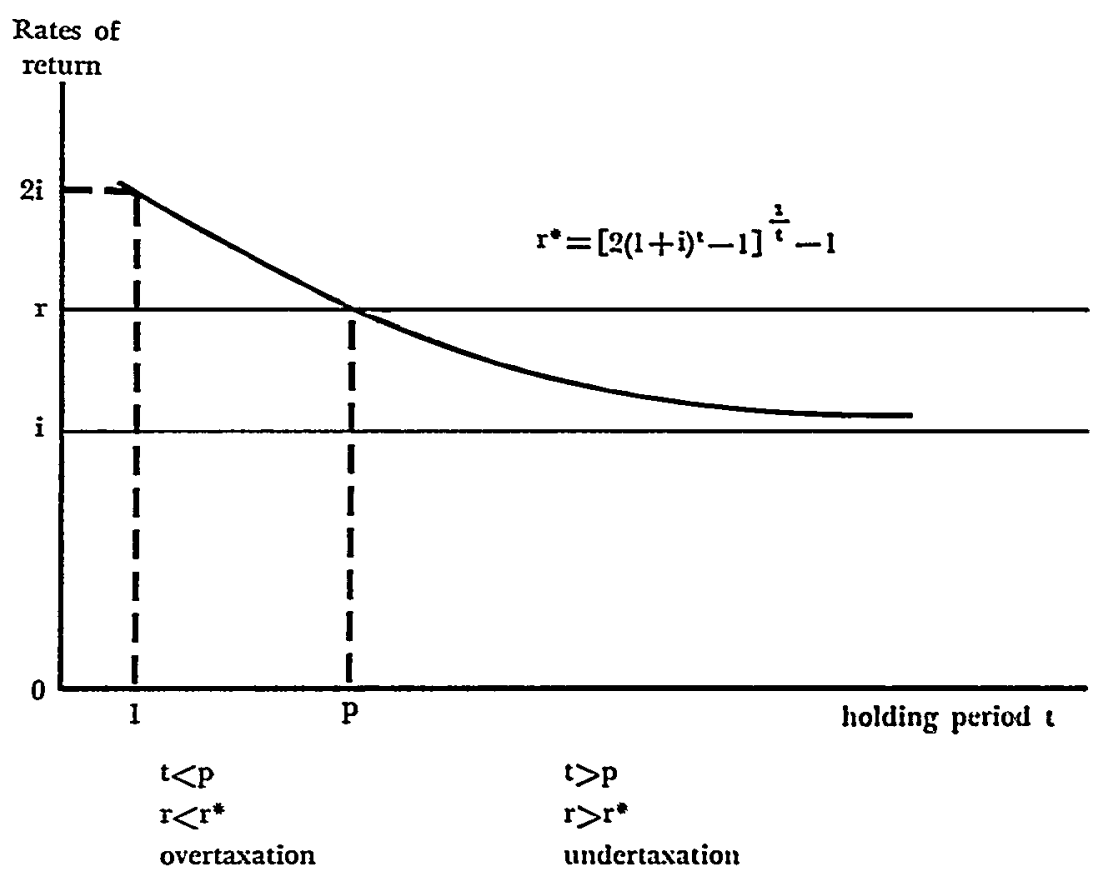

101. See, e.g., R. Goode, supra note 53, at 194-95; P. Stern, Tue Great Treasuri RAID 81-107 (1964).

102. The critical rate $r *$ depends on the cumulative rate of inflation during the period an asset is held. See notes 98, 100 supra. Only the crudest data, however, are available on the holding period distribution of capital assets and other property with bases. Compare McClung, The Distribution of Capital Gain on Corporate Shares by Holding Time, 48 REv. OF EcoN. \& STAT. 40 (1966) with Bailey, Capilal Gains and Income Taxation, in Taxation of Ixcome from CAprtal 15-26, 46 (A. Harberger \& $\mathrm{M}$. Bailey eds. 1969). 
The present restriction on the deductibility of capital losses ${ }^{103}$ also has implications for horizontal equity. Proper measurement of real income requires that real capital losses be deductible without limit from other income. ${ }^{104}$ The policy reasons for the present limitation on loss deductions are, however, largely independent of the effects of inflation. ${ }^{105}$ To the extent that these other policy goals are accepted, the present limitation need not be lifted entirely, as the proposed inflation adjustment does not disturb the rules governing the realiza. tion of loss.

\section{Vertical Equity}

Here the basic issue is whether a system of real income taxation enhances the progressivity of the Code. This question will require analysis of the various components of income.

Inflation theoretically results in a more regressive tax structure. This is true because the marginal rate of taxation increases with taxable income at a diminishing rate, ${ }^{100}$ and thus the real tax burden on individuals in the upper brackets does not increase as rapidly as that on those in the lower brackets. At the extreme, an individual who pays no tax on a nominal income of $\$ 2000$ will face an infinite increase in his real tax burden when inflation draws him into the tax. paying ranks. To the extent, then, that a system of real income taxation would prevent taxpayers from being pushed into higher brackets by illusory income gains, the benefits would be distributed inversely

103. $\$ 1211$.

104. See p. 719 supra.

105. There are two reasons for the restriction on capital loss deductions. First, since net long term capital gain is presently taxed at preferential rates, a person with a net long term capital loss would reap a tax benefit were the entire loss deductible from ordinary income. U.S. DEP'T OF THE TREAsURY, supra note 1, at 2, 19. See also H.R. REl'. No. 413 , 9lst Cong., lst Sess. 14 (1969). Therefore only half of such losses may be used to offset ordinary income. \$1211(b).

Second, the $\$ 1000$ annual limit on deductible net capital losses, $\$ 1211(\mathrm{~b})$, reflects a congressional concern about possible revenue loss since taxpayers can time realization of accumulated capital losses for maximum tax effect. U.S. DEP'T OF THE TREAsUkY, supra note 1 , at 2, 19.

106. The following table is calculated from the present rate structure applicable to married individuals filing joint returns. See $\$ 1$ (a).

Taxable Income

$\$ 0-\$ 10,001$

$\$ 10,001-\$ 20,001$

$\$ 20,001-\$ 35,001$

$\$ 35,001-\$ 50,001$

$\$ 50,001-\$ 200,001$

$\$ 200,001+$
Rate of Increase of Marginal Tax Rate per $\$ 10,000$ of Taxable Income

.57
.45
.21
.19
.08
0 
with the size of taxable income, and the progressivity of the income tax would be enhanced.

However, real income taxation might in other ways increase the regressivity of the Code. This redistributional effect would be caused by the relative holdings by different income groups of monetary assets, capital assets, and depreciable property. Indeed, it may well be that the rich would be the chief beneficiaries of a system of real income taxation.

The poor hold a smaller proportion of their wealth in net monetary assets (i.e., debt claims against others, less indebtedness) than do the rich, and thus gain relative to the rich from inflation. ${ }^{107} \mathrm{An}$ inflation-neutral system of income taxation would reduce this redistributional effect of inflation by according the rich greater loss deductions.

Similarly, net capital gains as a percentage of total income increases for higher income classes. ${ }^{108}$ Some commentators, recognizing this fact, have justified the present system's taxation of illusory capital gains as a type of wealth tax which enhances progressivity. ${ }^{100}$

Unless the preferential rates accorded to long-term capital gains were withdrawn, the chief beneficiaries of the floating basis adjustment would be upper income taxpayers who hold most capital assets. There is no reason, however, why Congress could not increase the progressivity of the Code by abolishing the preferential tax treatment for net property gain. In fact, the proposed inflation adjustment removes one of the major justifications of preferential treatment-that illusory gains should not be taxed. ${ }^{110}$ Elimination of the preferential rate structure would also make possible substantial simplification of the Code and end the ceaseless litigation over whether a particular item of income should be taxed at ordinary or preferential rates.

Finally, the use of a floating basis adjustment will increase the an-

107. R. Lampaan, Share of Top Wealth-Holders in National Wealmi 1922-56, at 135-55 (1962); D. Projector \& D. Weiss, Survey of Financial. Cilaracteristics of CoNSUMERs 15-17, 98 (1966); Mullineaux, Inflation Insurance: An "Escalator Clause" for Securities? Bus. Rev. OF Fed. Reserve BANK OF PHLL., Oct. 1972, at 7.

108. M. David, Alternative Aprroaches to Carttal Gains Taxition 81.80 (1968);

U.S. INternal Revenue Service, Dep't of the Treasury, Pub. No. 198, Statistics of

Income-1970 Individual Income Tax Returns, Prelminary, Table 4, at 29.30 (1972).

109. Those hardest hit by taxation of fictitious gains will be, in the main, not those who have suffered in other ways from the depreciation of money. Indeed, they will still be far better off than those whose property has been in the form of bonds. mortgages, and annuities. Taxation of fictitious gains, therefore, may serve to produce a not inequitable counterredistribution of income and property.

H. Simons, supra note 2, at 156 . McGovern partisans made the same point. See Vickrey, Party Planks on Federal Tax Reform, 1972 TAxition wrti Remesentation 439, 446.

110. See sources cited in note 2 supra. 
nual depreciation allowances for accelerated as well as straight line depreciation. ${ }^{111}$ Accelerated depreciation will therefore be even more "accelerated" than at present, and the economic distortions inherent in the use of such methods ${ }^{112}$ will be magnified. It should be emphasized that mere superimposition of the floating basis system ${ }^{113}$ on the present methods of computing depreciation will overcompensate owners of depreciable assets whenever there is a positive real interest rate, i.e., a market interest rate greater than the rate of inflation. ${ }^{114}$ Furthermore, the overcompensation is greatest for accelerated depreciation methods. The implications for vertical equity are clear, because the benefits of accelerated depreciation again accrue primarily to the rich and to corporations. ${ }^{115}$ It therefore appears that if the floating basis adjustment for depreciation were adopted, it should be accompanied by some limitation on the use of accelerated depreciation.110

\section{B. Revenue Effects}

Under the present system, the tax liability of each taxpayer, and hence aggregate federal tax revenues, increase annually in real terms. Three recent econometric studies have estimated that a one percent aggregate increase in adjusted gross income will increase federal tax revenue by approximately 1.4 percent. ${ }^{117}$ But the proposed system of

111. See note 31 supra.

112. See Brown, The New Depreciation Policy Under the Income Tax: An Economic Analysis, 8 NAT'L TAX J. 81, 96 (1955); Samuelson, Tax Deductibility of Economic De. preciation to Insure Invariant Valuations, 74 J. PoL. Ecos. 604 (1964).

113. See p. 719 supra.

114. This is a corollary to the proof where it was shown that the cumulated sum of floating basis depreciation allowances equaled replacement cost, when the nominal interest rate exactly equaled the rate of inflation. See note 27 supra. In a frec com. petitive market the probability of a zero real rate of interest is negligible, becausc money has a time value in real terms. I. FISHER, THEORY OF INTEREST 40 (1930). The floating basis adjustment would be non-distortional only in an imaginary world lacking positive real rates of interest. Such an imaginary world would be characterized by a non-productive capital stock and a zero rate of time preference. Id. at 186.92.

115. Depreciation on buildings in excess of straight line depreciation results in a revenue loss of approximately. $\$ 480$ million annually. Of this sum, $\$ 320$ million accrucs to corporations; $\$ 160$ million, to individuals. Statement of Edwin S. Cohen, Under Sceretary of the Treasury, before the Joint Economic Committee, app. D, July 21, 1972. The Asset Depreciation Range System (ADR) produces a revenue loss of $\$ 700$ million, of which $\$ 100$ million accrues to individuals, and $\$ 600$ million to corporations. Id. The tax benefits to individuals are distributed primarily in the upper income brackets, morc than seventy-six percent accruing to individuals with AGI in excess of $\$ 15,000$. Sec id. app. $\mathbf{E}$.

116. The twenty percent leeway in the ADR System, Treas. Reg. $\$ 1.167(a) \cdot 11(a)(4)$ (1971), and the use of the sum-of-the-digits and declining balance methods of computing depreciation, $\$ \S 167(\mathrm{~b})(3),(4)$, could be abolished.

117. V. TANZI, The Individual Income TAX AND Economic Growti 105.09 (1969); Blackburn, Implicit Tax Rate Reductions with Growth, Progressive Taxes, Constant Progressivity, and a Fixed Public Share, 57 AM. Econ. REv. 162 (1967); Mishan \& Dicks. Mireaux, Progressive Taxation in an Inflationary Economy, 48 AM. EcoN. REv. 590 (1958). 
real income taxation will result in revenues increasing at just the rate of inflation, thereby remaining constant in real terms, for increases in total income which are not due to real economic growth. It is not clear whether the prices of goods and services purchased by the government have increased at a rate faster than the rate of overall inflation. ${ }^{118}$ If they have, annual real tax increases may be necessary in order for the government to maintain the present level of services; even if the costs of government increase no faster than the overall rate of inflation, annual real tax increases will be necessary for any expansion. The present rapidly increasing demand for public services, as indicated by the federal budget which is rising much faster than the rate of inflation, seems to indicate that for one reason or another the real costs of government are increasing. ${ }^{110}$

This, in itself, does not decide the issue for or against a system of real income taxation. Any of the revenue losses under such a system could be recovered by increasing tax rates. The critical issue is whether the political difficulty of obtaining congressional approval for such explicit tax increases, when combined with a need for increasing revenues, justifies a system of hidden annual increases.

Still, the magnitude of the revenue "lost" through an inflationneutral system should not be underestimated. Only one change among all those proposed-the reduction of the interest deduction to reflect income from reduced real debt obligations-would increase tax yield; revenue losses would result from all the other proposed changes. An important loss would arise from the fact that an inflation-neutral system would increase a host of fixed dollar deductions, exemptions, and exclusions as well as the widths of marginal rate brackets. Although the size of any particular exemption, deduction, or exclusion may only increase by a small amount per individual taxpayer, the aggregate sums may be quite large. ${ }^{120}$

The aggregate revenue loss may be estimated by using the elasticity factors noted above. ${ }^{121}$ Institution of the system in $1973,{ }^{122}$ assuming

118. C. Shultz, E. Fried, A. Rivlin \& N. Teeters, Settinc National Priortties: Tue 1972 BUDGET 329-31 (1971).

119. Id. at 12-24.

120. For example, the amount of the personal exemption for calendar year 1971 was increased from $\$ 650$ to $\$ 675$. Revenue Act of 1971 , Pub. L. No. 92-178, 85 Stat. 497, an increase of 3.85 percent. This is comparable to recent rates of inflation: The rate of inflation in 1971 as measured by the GNP implicit price deflator was 4.63 percent. U.S. PRESIDENT, ECONOMIC REPORT OF THE PRESIDENT Table B-3, at 193 (1972). This $3.8 \mathrm{~J}$ percent increase in the personal exemption was calculated to produce a revenue loss of $\$ 925$ million. H.R. REP. No. 533, 92d Cong., Ist Sess. $35-36$ (1971).

121. See sources cited in note 117 supra.

122. Estimated 1973 personal income tax revenues are $\$ 99.4$ billion. N.Y. Times, Jan. 30,1972 , at 21 , col. 2 (city ed.). 
four percent inflation during the year, would lead to a first year revenue loss of about $\$ 1.6$ billion. ${ }^{123}$

These estimates are relevant only for tax revenue from the individual income tax, and should therefore be considered as lower limits to the expected revenue loss of an inflation-neutral system. Two additional considerations are also omitted from the estimates. First, the corporate income tax yield is likely to be significantly affected by the floating basis adjustment for depreciation. ${ }^{124}$ Second, the completely new treatment of creditors and debtors-not reflected in the tax elasticities-may also lead to rather substantial revenue losses due to the fact that the government would not be able to tax itself on the "gain" it receives as a debtor while its creditors-those who hold the debt-would be able to deduct their inflation "loss." 225

\section{Macroeconomic Stabilization}

A progressive income tax is one of the major tools of government fiscal policy. It is often called an automatic stabilizer because it cushions fluctuations in national income. During periods of boom,

123. Assume that from one year to the next total AGI increases by $S$ percent, of which $r$ percent represents real growth and $i$ percent represents inflation. If the mul. tiplier is $(I+m)$, then nominal tax revenues under the present tax system will increase by about $(1+m) S$, or $(1+m)(r+i)$ percent. Under a system of real income taxation, the multiplier for the inflationary increase in AGI would be 1. Assuming that the multiplicr for the real increase in AGI in unchanged, nominal tax revenues under the proposed system would increase by $(1+m) r+i$ percent. The revenue loss under the proposed system is thus equal to approximately mi percent. Assuming a multiplicr of 1.4 (sec note 117 supra) and inflation of four percent, the first year loss would be about 1.6 percent of total personal income tax revenues. See note 122 supra.

124. An inflation-neutral system of taxation would permit the present allowable depreciation deductions to be magnified by the cumulative rate of inflation calculated from an asset's date of acquisition. See pp. 720-24 supra. A rough approximation of the revenue effect can be made by multiplying the past reported depreciation allow. ances by an inflation factor and calculating the revenue loss on an estimate of aggregate marginal tax rates.

Using depreciation claimed on all 1968 corporate tax returns, a four percent rate of inflation would have increased by $\$ 1.775$ billion the $\$ 44.4$ billion actually taken. U.S. Internal Revenue Service, Dep't of the Treasury, Pub. No. 159, Statistics of IncomeCORPORATION INCOME TAX RETURNS 1968 (1972). With a marginal corporate tax rate of forty-eight percent, the first year loss would have been roughly $\$ 852$ million. This is a conservative figure because the allowances will increase as investors respond to the tax subsidy by investing in more depreciable plant and equipment. Moreover the $\$ 14.4$ billion claimed depreciation does not account for the recently enacted Assct Deprcciation Range system which substantially increases depreciation allowances, See Treas. Reg. \$ 1.167(a)-11(a)(4).

125. A four percent inflation would produce a $\$ 9.97$ billion decline in the real valuc of the privately held national debt. Table, Ownership of Public Debt, Fed. RESERve BuLL, Oct. 1972, at A 44. If the average marginal tax rate of the holders of the debt is twenty-five percent, the revenue loss is on the order of magnitude of \$2.5 billion.

The net revenue impact due to the adjustment of private debt will depend on the relative indebtedness and the ownership of debt claims of the various income groups: The creditor-debtor adjustments will cancel themselves out only if the debtors and creditors are in the same marginal tax brackets. 
tax revenues rise more rapidly than aggregate income, thus dampening aggregate demand. Recession, on the other hand, automatically moves the budget toward greater deficits and fiscal stimulus as revenues fall. ${ }^{126}$

Real income taxation has been criticized because it will reduce this effect of the tax structure: ${ }^{12 \pi}$ Tax yields will not rise as quickly as they do now from inflationary shocks, nor will they fall as rapidly in periods of recession.

While this criticism is somewhat valid, the importance of automatic stabilizers should not be exaggerated. The built-in flexibility of the Code can only reduce a small fraction of the fluctuation in aggregate income. Discretionary fiscal and monetary policy will still be necessary to achieve the proper balance of full employment and moderate inflation.128

It should also be remembered that a system of real income taxation remains a progressive income tax system. The progressivity of the income tax system, however, will be maintained in real rather than nominal terms. Exogenous shocks to the economy will still generate increasing real tax revenues which will partially offset aggregate fluctuations.

A system of inflation-neutral taxation may even aid in the pursuit of macroeconomic objectives. There is some evidence that constant real rates might reduce the short term pressure of wage inflation:120 Wage earners who are assured that their net after-tax real take home pay will not be eroded by higher real tax rates should not have as great an incentive to make exorbitant wage demands.

A possible defect with the system, however, involves its peculiar lag structure. Tax reduction to correct for inflation will necessarily take place in the year after inflation has occurred. This tax reduction may in fact accentuate rather than counter unsettling forces in the economy. ${ }^{130}$ Though resolution of this question is by no means an easy undertaking, it should be noted that modern econometric models

126. See generally R. Goode, supra note 53, at 286.307; J. Pecimas; fenenal Tax Policy 11-14 (1971); P. Samuerson, Economics 332-34 (8th ed. 1970).

127. E. Brown, Depreciation ADjustarests for Price Cilanges 78.92 (1952); R. Goode, supra note 53 , at 192-93.

128. See P. SAMUELSON, supra note 126, at 333-34.

129. O. Echstein \& R. BRINner, The INFlation Process in tile UNited States, A Study Prepared for the use of the Joint Economic Comartere, 92d Cong., 2d Sess. 3-4, 17-18 (1972).

130. If the government desired to bring intlation under control, it would pursue monetary and fiscal policies in 1973 designed to reduce aggregate demand. If tax payments made in 1973 were reduced, however, as a result of not taxing inflation.gencrated gains in 1972 , countercyclical stabilization policy might be thwarted. 
are already built on rather intricate lagged relationships between monetary, fiscal, investment, and consumption variables, ${ }^{131}$ and there is no a priori reason to believe introduction of this additional lagged relationship will either increase or decrease the overall stability of the system.

\section{Conclusion}

An analysis of the impact of inflation on the income tax structure of the United States discloses a wide range of effects on many different elements of income. A consistent system of real income taxition would require: (1) adjustments to the basis of property for the purpose of depreciation as well as for the computation of gain or loss; (2) annual adjustments to account for real gain or loss due to reductions in the value of fixed indebtedness obligations; (3) annual adjustments to deductions now fixed in nominal dollar terms; and (4) annual adjustment to the tax tables to widen the nominal brackets. Many of the theoretically complex computations necessary to implement these adjustments can be easily incorporated into the standard tax forms, and an inflation-neutral tax system should not, therefore, be dismissed as administratively infeasible.

Nevertheless, merely superimposing a system of real income taxation on the present tax structure may present difficult questions of both taxpayer equity and intricate economics. But these problems may be offset by a new measure of political accountability which should accompany the elimination of disguised tax increases-increases which now occur without the free and open discussion which should precede all difficult decisions of taxation.

131. See, e.g., Ando \& Goldfield, An Econometric Model for Evaluating Stabilization Policies, in Studies in Economic Stabilization 215 (A. Ando, E. Brown, \& A. Friedlacnder eds. 1968). 